\title{
A Study on Lock-In Effect of Capital Gains Tax for Securities in Taiwan Stock Market-An Application of DID Model
}

\author{
Ming-Min Lo \\ Department of Finance, Chaoyang University of Technology, Taichung, Taiwan \\ Email: $\underline{\text { mingminlo@cyut.edu.tw }}$
}

Received 4 August 2015; accepted 8 September 2015; published 11 September 2015

Copyright (C) 2015 by author and Scientific Research Publishing Inc.

This work is licensed under the Creative Commons Attribution International License (CC BY). http://creativecommons.org/licenses/by/4.0/

c) (i) Open Access

\begin{abstract}
In this study, we applied classical linear regression model and DID model while minimized the effects of international markets to investigate the short-term and long-term lock-in effects following the announcement of the capital gains tax for securities in Taiwan stock market. Capital gains tax was reintroduced in 2013 in Taiwan, with stocks and securities being the main focus of taxation to prioritizing capital gains tax reform to improve the tax system and promote tax fairness. Although the government's primary consideration is generating tax revenue, scholars have long advocated establishing a fair tax system. However, levying a tax on capital gains for securities would affect the stock market, causing investors to become wary of any investments associated with the capital gains tax. The challenge of balancing the interests of different groups has made the capital gains tax for securities difficult to implement. The empirical results showed the evidence that the changes in trading volume of the Taiwan stock market exhibited negative short-term and long-term lock-in effects caused by the capital gains tax for securities as compared with those in Hong Kong's stock market. The lock-in effect on Taiwan's stock trading volume led to a depression in Taiwan's capital market and reduced another key source of tax revenue for the government (the securities transactions tax). The overall impacts of the tax appear to have generated a loss greater than the gain.
\end{abstract}

\section{Keywords}

Lock-In Effect, Capital Gains Tax for Securities, Difference in Difference Model, Tax Neutrality Principle

\section{Introduction}

In Taiwan capital gains tax on securities transactions (hereafter capital gains tax for securities) was reintroduced 
in January 2013, with stocks and securities being the main focus of taxation to prioritizing capital gains tax reform to improve the tax system and promote tax fairness. Although the government's primary consideration is generating tax revenue, scholars have long advocated establishing a fair tax system. However, levying a tax on capital gains for securities could affect the stock market, causing many investors to become wary of any investments associated with the capital gains tax due to the increases of the investment costs. The challenge of balancing the interests of different groups has made the capital gains tax difficult to implement.

Since the Taiwan Stock Exchange market was founded in 1953, capital gains tax for securities has been levied numerous times, three of which are relatively important: first in March 1973 (repealed in 1975), second in January 1989 (repealed in 1990), and third in January 2013 (currently in effect). The current capital gains tax for securities has undergone three amendments. Since the announcement of this policy, the trading volume of Taiwan's stock market has exhibited a market decline. Despite the government constantly introducing numerous stock market revitalization programs during this period, such efforts have been ineffective in increasing the stock market trading volume. The Ministry of Finance [1] has proposed on multiple occasions that the stock market trading volume is connected to fundamentals and international environmental factors. However, at the end of 2014, the provisions of the individual capital gains tax for securities were re-revised in response to public pressure and the consistently weak trading volume. The large term capital gains tax for securities levied on individual stock transaction exceeding NT \$1 billion, having a relatively strong influence on the stock market trading, was amended and temporarily repealed until January 2018.

Fairness and efficiency are key issues in taxation reformation, and their relationship influences the direction and outcomes of the government implementing its tax policy. The fairness of the income tax burden from trading stocks is maintained on the principles of "ability-to-pay" and "justice as fairness.” The levying of capital gains tax for securities is justified on the basis of tax fairness, and the tax base of capital gains on securities is thus recognized under the principle that any and all income should be taxable. Nevertheless, because of capital market developments and government inefficiency in taxation, imposing this tax appears to have affected investors' (taxpayers') behavior. Thus, it has a crucial impact on capital market development, taxation efficiency, Taiwan's taxation income, and economic growth. Although all income should be taxed on the basis of fairness principle. However levying of capital gains tax for securities might cause a "butterfly effect" and affect market investors' confidence and behavior through taxation announcement and resulting into both micro-economic and macro-economic impacts.

The purpose of this paper is to investigate whether or not that levying of a capital gains tax for securities in Taiwan affected the stock market trading volume and investors' behavior. The theoretical and practical significance of this paper is based on the principle of tax neutrality to claim that levying of capital gains tax for securities should not influence securities market development despite the intension of taxation satisfactions. The present paper intends to investigate the main cause of the decline of Taiwan stock market trading volume by the capital gains taxation announcement influence through empirical study basing on the stock market impact (investor behavior aspect) and taxation impact (tax revenue aspect). The results might serve as a reference for development of future government taxation policies.

\section{Literature Review}

This section explores literature on capital gains tax for securities influence on taxation policy, investor behavior, and securities markets as follows:

\subsection{Transmission Mechanisms of Tax System and Behavioral Finance}

Yin (2005) [2] indicates that the transmission mechanism of taxation in capital markets exert both income effects and substitution effects through investor expectations, financial commodity price mechanisms, and investor transaction cost mechanisms, to attain distribution and regulation functions and substantially influencing capital markets and macroeconomic conditions. The transmission mechanism of taxation in capital markets could be assorted into three stages: 1) the government releases tax policy signals and changes in taxation; 2) investor interests and behaviors in the virtual economy (financial market) undergo change; and 3) socioeconomic activities in the real economy are transformed.

As a tax is levied on capital gains for securities, the government releases relevant policy information. Although such policies are aimed at increasing tax revenue for government, to securities investors, releasing new 
information and increasing the tax burden of investors by introducing a capital gains tax for securities also increases the costs of investing in securities. This increased cost has diminishes investor expectations on investment income. The information on the taxation system and the effects of the tax burden lead to changes investment-related decisions and behaviors because they induce change in investor income expectations and investing interests. The income effect and substitution effect directly or indirectly influence the overall capital market, economic activity, tax policy outcomes, and resource allocation.

\subsection{The Impact of Capital Gains Tax on Investor Behavior in Securities Markets}

A capital gain or loss is essentially an appraisal of an investor's assets: a capital gain occurs as the closing asset value is higher than the opening asset value, whereas a capital loss occurs when the closing asset value is lower than the opening asset value. Levying a capital gains tax on securities generally has the impacts on investor behavior such as the effects of bunching, lock-in, and tax avoidance.

1) Bunching Effect

The opening purchase of assets and closing disposal of them do not occur simultaneously, and the realized capital gains are regarded as taxable income. In a progressive tax system combining the payment of taxes on capital gains and individual income, the long term capital gains are taxed as a one-time taxation. Thus, taxpayers with long-term capital gains income are accordingly taxed in the tax payment period when the gains are realized. If a relatively high progressive income tax rate applicable to the higher income investors, then the tax burden might be regarded as unfair. Feldstein and Yitzhaki (1978) [3] empirically showed the evidence that the taxpayer investment decisions are extremely sensitive to changes in taxation. Jin (2006) [4] found that capital gains tax is an impediment to selling by some investors. Especially in tax-sensitive investors who are sensitive to cumulative capital gains in selling decision, on the other hand tax-exempt investors are not obvious. Capital gains tax for securities has a significantly negative impact on investor behavior in selling and converting shares of common stock.

2) Lock-In Effect

The prior studies indicated that the lock-in effect from taxing capital gains for securities can be viewed as the impact of a tax burden on investment decisions. Investors' preferring to avoid such tax burdens tend to reduce their participation in stock-investing activities or even discontinue investing in stocks in order to invest on lowtax or tax-free investment commodity. This change in investor behavior would reduce or stagnate stock market trading volumes, affecting the liquidity of stock market trading and often intensifying price fluctuations. Somers (1948) [5] documented that taxes on capital gains for securities typically cause a lock-in effect in stock markets, primarily because investors become less willing to invest or they wish to avoid taxation. Stiglitz (1983) [6] also indicated that capital gains tax for securities are detrimental to the development of securities markets, arguing that levying taxes on capital gains increases asset transfer costs and reduces transaction efficiency, causing a lock-in effect on trading volume. Dai et al. (2008) [7] demonstrated that the equilibrium impact of capital gains taxes reflects both the capitalization effect (i.e., capital gains taxes decrease demand) and the lock-in effect (i.e., capital gains taxes decrease supply). Sahm (2008) [8] has found taxation of capital gains upon realization instead of accrual provides incentives to hold winners as long as possible and sell losers immediately. The lock-in effect possibly distorts the liquidation and investment decision. Such market inefficiency increases stock market volatility, further reducing the willingness of investors to trade and intensifying the lock-in effect.

3) Tax Avoidance Effect

Another effect of levying a tax on capital gains for securities is that it could cause investors to adjust their trading decisions to avoid paying taxes. To avoid paying tax, investors may realize their capital gains earlier before the taxes are introduced, or they may defer the time they realize them to delay their tax payment. Tax avoidance or delay often results in asset price reversals. Poterba (1987) [9] pointed out that raising the marginal tax rate will increase tax avoidance chances. Reese (1998) [10] showed that when the long-term capital gains tax rate is lower than the short-term capital gains tax rate, investors coordinate the timing of realizing their capital gains and losses to reduce their taxable income. George and Hwang (2007) [11] has found investors would delay selling profitable stocks to the beginning of next year in order to avoid capital gains tax. George and Hwang (2007) indicated the lock-in effect to be the main cause of U.S. stock market long-term price reversals.

\subsection{Behavioral Finance}

Somers (1948) [5] and Dai et al. (2008) [7] indicated that capital gains taxes for securities create a lock-in effect 
in securities markets, affects investors' trading confidence and amplify volatility. In addition, such taxation is detrimental to market price stability. Stiglitz (1983) [6] and Sahm (2008) [8] argued that levying a tax on capital gains for securities causes a lock-in effect in stock market by increasing the cost of transferring asset ownership to investors and reducing the efficiency of transactions. Market inefficiency increases stock market volatility and reduces the willingness of investors to invest in securities markets, further intensifying the lock-in effect. Feldstein and Yitzhaki (1978) [3] and Jin (2006) [4] showed that levying a tax on capital gains for securities has a significantly negative influence on the trading and switching of stocks. Investment decisions are extremely sensitive to changes in the tax burdens on investors. Stock conversions are particularly sensitive to changes in the capital gains tax policy for securities. Such taxation policy changes would significantly reduce investor willingness to sell or trade stocks and inducing a lock-in effect on trading volume. When the reduction in investor willingness to sell or change their holdings because of increased tax rates reaches a critical threshold, a reduction in stock liquidity becomes inevitable. Falsetta et al. (2013) [12] points out a tax reduce shall encourage the taxpayer to increase risky investment while a tax increase shall discourage the taxpayer to decrease risky investment. Therefore capital gains tax for securities shall alter the taxpayer on the investment preference. George and Hwang (2007) [11] also indicated investors would delay selling profitable stocks to the beginning of next year in order to avoid capital gains tax, the lock-in effect might be the main cause of U.S. stock market longterm price reversals. According to Feldstein and Yitzhaki (1978) [3] and Dai et al. (2008) [7] examined the behavioral outcomes of selling and converting shares of common stock, it appear show that the elasticity of demand for shares of common stock is greater at that time due to the increase on capital gains tax rate for securities.

Henderson (1990) [13] showed that most studies on the lowering of capital gains tax rates in the United States in 1978-1981 report increases in trading volume, thereby increasing tax revenues, showing that capital gains tax rate correlates negatively with trading volume. However, Henderson also examines the United States Tax Reform Act of 1986 and showed that increasing the capital gains tax rate did not reduce the overall stock market trading volume; accordingly, when disposing of or trading stocks, investors are primarily concerned with investment gains or losses and investment portfolio. The capital gains tax rate was not a major consideration. Thus, Henderson argues that the capital gains tax for securities is not significantly related to stock market trading volume. Slemrod (1982) [14] also demonstrated that after the individual capital gains tax was lowered in the United States in 1978, stock market trading volumes increased rapidly. However, although the empirical results on the New York Stock Exchange during this time support the influence of the tax cut on the increase in trading volume, the empirical results on the American Stock Exchange indicate only a negligible effect. Therefore, it remains unclear whether the increase in trading volume was caused by the tax cut, the stock market boom at that time, or other factors.

Gemmill (1956) [15] posited that most investors aim to maximize their stock earnings. Disposal decisions on common stock investment should be made primarily under the expectation that current stock prices have peaked and are unlikely to increase further in the near future; only then should investors sell their shares and convert them to purchase other assets that are more profitable. Therefore, Gemmill (1956) [15] argued that investor trading is not limited by the desire to avoid paying tax, indicating that the influence of taxation on securities markets is minimal. Bhootra (2013) [16] argued that locked-in capital gains do not explain the reversals in longterm return of U.S. stock market by tax effects. The reversals for intangible information return due to investors are long lasting and robust to controls for growth in assets and capital expenditures; the overreaction still explains reversal patterns in U.S. stock returns.

\section{Empirical Model}

In this study, we examine whether the levying of a capital gains tax for securities in Taiwan influenced the stock market trading volume and investor behavior. This study further examine whether its effect on stock market trading volume (a key source of tax revenue derived from the securities transactions tax) has affected tax revenues and the securities market and industry. Therefore, we investigate whether the changes in short-term and long-term stock market trading volume associate significantly with the government announcing that they would be levying a tax on capital gains for securities. To exclude the impact of international factors, stock market trading volume is examined with the Taiwan Stock Exchange [17] serving as an experimental group and the Hong Kong Stock Exchange [18] acting as a comparison group. A classical linear regression model and difference-indifferences (hereafter DID) model are adopted to test whether the levying of a tax on capital gains for securities 
in Taiwan caused a lock-in effect in Taiwan's stock market during this period, thereby affecting Taiwan's macro economy (e.g., capital market development and government fiscal revenue) and micro economy (e.g., investor behavior, stock market structure, and the operation of the securities industry).

\section{Classical Regression Model and DID Model}

In order to examine whether the government's levying of a tax on capital gains for securities resulted in shortterm and long-term lock-in effects in Taiwan's stock market. The stock market trading volume is set to be an explained variable. The short-term and long-term lock-in effects are observed during the implementation periods since March 28, 2012 to September 29, 2014 following the announcement by the government of Taiwan that it would be imposing a tax on capital gains for securities. Stock market rate of return, amplitude rate, and 30-day average rate of return are also included in the explanatory variables.

1) Classical Linear Regression Model

The classical linear regression model could be written as Equation (1):

$$
Y_{t}=\alpha+\beta_{1} \times \text { Time }_{t}+\sum_{i=1}^{n} \gamma_{i} X_{i t}+\varepsilon_{t}
$$

where $Y_{t}$ denotes the stock volume traded in the market; Time ${ }_{t}$ is a dummy variable indicating whether the capital gains tax for securities had been announced (before the announcement $=0$; after the announcement $=1$ ); $X_{i t}$ represents the other explanatory variables including the return rate of each stock market during the current period (R), the amplitude rate of each stock market (W), and the 30-day average return rate of stock market (R30); $\alpha$ is a constant term; $\varepsilon_{t}$ is a residual; and $\beta_{1}$ is the time effect test coefficient, indicating the effect of the announcement on $Y_{t}$ after the announcement date.

2) Difference in Difference Model

In the classical linear regression model, it might lead the problem of overestimation due to the sample selection bias or other factors that are difficult to control. Ashenfelter and Card (1985) [19] proposed the DID model to overcome this overestimation problem. For the DID model, samples are classified into an experimental and comparison group (Lin, 2013 [20]). The differences between the experimental and comparison groups before a policy was announced are subtracted from the differences between the two groups after the policy was announced. These differences indicate the true effects of the tax policy. In the choosing of comparison group, according to $\mathrm{Lu}$ (2002) [21] studying the spillover effects of stock markets indicates Taiwan stock market, U.S. stock market, Japan stock market, Hong Kong stock market and China mainland stock market are co-integrated. The conditional correlation coefficients among those in Taiwan stock market, Hong Kong stock market, and China mainland stock market were relatively significant, demonstrating a certain degree of correlation among these three markets. The strongest correlation was between those in Taiwan and Hong Kong. The announcement of the capital gains tax for securities on March 28, 2012, primarily influenced the stock market in Taiwan. To exclude the impact of international factors, we used the trading volume on the Taiwan stock market (TW) as the experimental group and that of the Hong Kong stock market (HK) as the comparison group. The trading volume of these two stock markets was analyzed.

The DID model is constructed as Equation (2):

$$
Y_{i t}=\alpha+\beta_{1} \times \text { Time }_{t}+\beta_{2} \times \text { AREA }_{i}+\beta_{12} \times \text { Time }_{t} \times A R E A_{i}+\sum_{i=1}^{n} \gamma_{i} X_{i t}+\varepsilon_{t}
$$

where $Y_{t}$ denotes the stock volume traded in the market; Time $_{t}$ is a dummy variable indicating whether the capital gains tax for securities had been announced. In contrast to classical model, two dummy variables are included in this model: $A R E A_{i}$ and Time $_{t} \times A R E A_{i}$. The term $A R E A_{i}$ is a dummy variable indicating the economy effect (Taiwan stock market $=1$; Hong Kong stock market $=0$ ). The expression Time ${ }_{t} \times A R E A_{i}$ is referred to as the cross-effect of temporal and economy factors. In the DID model, the term $X_{i t}$ represents the other explanatory variables, including the return rate of each stock market during the current period $(\mathrm{R})$, the amplitude rate of each stock market (W), and the 30-day average return rate of stock market (R30). A particularly critical aspect of the DID model is the $\beta_{12}$ cross-effect coefficient, if the announcement of the capital gains tax for securities had a major influence on Taiwan's stock trading volume, than the degree of reduction in Taiwan's stock trading volume should be less than that in Hong Kong's stock trading volume. The degree of influence could be investigated through the estimation of the $\beta_{12}$ cross-effect test coefficient. 


\section{Empirical Results}

\subsection{Data and Descriptive Statistics}

Table 1 is drawn from the database of Datastream including the closing price, highest price, lowest price, and total volume of stocks traded for Taiwan Capitalization weighted stock index of Taiwan Stock Exchange and Hong Kong Hang Seng stock index of Hong Kong Stock Exchange to calculate each index's rate of return (R), amplitude rate of each stock market (W), and 30-day rate of return (R30), which served as explanatory variables.

The stock trading volume of each market was the explained variable. Three dummy variables were also employed: First, for the time-effect variable, the start of the implementation period was March 28, 2012 (when the capital gains tax for securities was announced in Taiwan); for observations after this period, this dummy variable was set to 1 , otherwise 0 . Second, for the regional economy effect variable, the value was set to 1 for transactions on the Taiwan Stock Exchange (experimental group) and 0 for the Hong Kong Stock Exchange (comparison group). Third, for the cross-effect variable, the product of the temporal and economy factors was used to determine whether the amplitude of the reduction in Taiwan's stock trading volume was greater than that in Hong Kong's stock market following the announcement of the capital gains tax for securities.

To observe the impact of the short-term and long-term lock-in effects on stock trading volume after Taiwan's capital gains tax for securities was announced, we classified this sample data into two periods: For the shortterm effect, the observation period was set from January 1, 2007 to November 30, 2012. We examined the shortterm impact of the announcement of the capital gains tax for securities on stock trading volume during the 8 months following the announcement of this policy (March 28, 2012 to November 30, 2012). For the long-term effect, the observation period was set from January 1, 2007 to September 29, 2014. We observed the changes in stock trading volume during the implementation of the capital gains tax for securities over a longer period (March 28, 2012 to September 29, 2014).

Table 1. Descriptive statistics.

\begin{tabular}{|c|c|c|c|c|c|c|}
\hline \multicolumn{7}{|c|}{ Short term-observation period (2007/1/1-2012/11/30) } \\
\hline & Mean & Median & Maximum & Minimum & Std. Dev & Obs. \\
\hline Trading volume (TW) & 112153.9 & 108273.0 & 322003.0 & 23837.00 & 38300.48 & 1465 \\
\hline Day return rate (TW) & $8.55 \mathrm{E}-05$ & 0.000998 & 0.067422 & -0.065133 & 0.014621 & 1465 \\
\hline Amplitude rate (TW) & 0.015291 & 0.012271 & 0.072320 & 0.002949 & 0.010207 & 1465 \\
\hline 30-day return rate (TW) & $7.08 \mathrm{E}-05$ & 0.000406 & 0.009446 & -0.011842 & 0.002872 & 1465 \\
\hline Trading volume (HK) & 26197.27 & 23281.00 & 102603.0 & 6995.000 & 11387.39 & 1463 \\
\hline Day return rate (HK) & 0.000257 & 0.000607 & 0.143471 & -0.127000 & 0.019487 & 1463 \\
\hline Amplitude rate (HK) & 0.016591 & 0.013475 & 0.163298 & 0.003193 & 0.011980 & 1463 \\
\hline 30-day return rate (HK) & 0.000285 & 0.000472 & 0.011534 & -0.018465 & 0.003243 & 1463 \\
\hline \multicolumn{7}{|c|}{ Long term-observation period (2007/1/1-2014/9/29) } \\
\hline & Mean & Median & Maximum & Minimum & Std. Dev & Obs. \\
\hline Trading volume (TW) & 106261.1 & 100011.0 & 322003.0 & 23837.00 & 36035.43 & 1910 \\
\hline Day return rate (TW) & 0.000159 & 0.000911 & 0.067422 & -0.065133 & 0.013222 & 1910 \\
\hline Amplitude rate (TW) & 0.013445 & 0.010312 & 0.072320 & 0.002601 & 0.009663 & 1910 \\
\hline 30-day return rate (TW) & 0.000185 & 0.000459 & 0.009446 & -0.011842 & 0.002567 & 1910 \\
\hline Trading volume (HK) & 25482.22 & 23003.00 & 102603.0 & 6995.000 & 10606.61 & 1911 \\
\hline Day return rate (HK) & 0.000234 & 0.000504 & 0.143471 & -0.127000 & 0.017619 & 1911 \\
\hline Amplitude rate (HK) & 0.015019 & 0.012057 & 0.163298 & 0.003193 & 0.011085 & 1911 \\
\hline 30-day return rate (HK) & 0.000295 & 0.000507 & 0.011534 & -0.018465 & 0.002932 & 1911 \\
\hline
\end{tabular}

Data sources: The stock trading information of Taiwan Stock Exchange weighted stock index and Hong Kong Hang Seng Stock Exchange stock index from Datastream financial database. 
Table 1 shows the denomination value for trading volume of each stock market is different. Because the currencies are different and per unit value differs, Taiwan market is denominated using NT \$1 million and Hong Kong market is denominated using HK \$1 million. The differences between the highest and lowest trading volume values in each market are relatively large. Therefore, we used the logarithms of stock trading volume for observation to narrow the differences between the values.

\subsection{Short-Term Effects (Post Announcement)}

\section{1) Estimates of Classical Regression Model}

The empirical results in Table 2 show that trading volume in the Taiwan stock market decreased by $36.5 \%$ in the short-term period. The time effect was significantly negative at the $1 \%$ level. Theoretically, Taiwan's capital gains tax for securities should not affect neighboring regions such as Hong Kong stock market. However, trading volume in the Hong Kong stock market decreased by $21.1 \%$, indicating that international factors such as the European debt crisis may have influenced stock market trading volume in this period. Additionally, with the exception of the daily rate of return, all other variables such as daily amplitude rate and 30-day return rate correlated positively at a $1 \%$ level of significance. This result also shows that the magnified stock market amplitude rate and long-term rates of return in stock markets positively influenced the trading volume.

2) Estimates of Difference in Difference Model

To clarify whether international factors influenced the reduction in trading volume in Taiwan's stock market after the announcement date, we performed an analysis using the DID model with Hong Kong stock market set as the comparison group. Table 3 shows that the time-effect variable after the announcement date indicates that

Table 2. Estimates of classical regression model (short-term).

\begin{tabular}{|c|c|c|c|c|c|c|}
\hline \multirow[t]{4}{*}{ Period } & \multicolumn{6}{|c|}{ Short-term-2007/1/1-2012/11/30 (announcement day: 2012/3/28) } \\
\hline & \multicolumn{3}{|c|}{ Experimental group } & \multicolumn{3}{|c|}{ Comparison group } \\
\hline & \multicolumn{3}{|c|}{ Trading volume effect-TW (Y) } & \multicolumn{3}{|c|}{ Trading volume effect-HK (Y) } \\
\hline & Coefficient & Standard error & p-value & Coefficient & Standard error & p-value \\
\hline Intercept (C) & $11.534^{* * *}$ & 0.0144 & 0.0000 & $9.896^{* * *}$ & 0.0170 & 0.0000 \\
\hline Time effect & $-0.365^{* * *}$ & 0.0225 & 0.0000 & $-0.211^{* * *}$ & 0.0283 & 0.0000 \\
\hline Day return rate & 0.089 & 0.4988 & 0.8571 & -0.109 & 0.4649 & 0.8138 \\
\hline Amplitude rate & $4.839^{* * *}$ & 0.7618 & 0.0000 & $13.087^{* * *}$ & 0.7947 & 0.0000 \\
\hline 30-day return rate & $62.971^{* * *}$ & 2.6898 & 0.0000 & $22.572^{* * * *}$ & 2.9322 & 0.0000 \\
\hline R-squared & & 0.3993 & & & 0.2182 & \\
\hline
\end{tabular}

Notes: ${ }^{* * *}$ Significant level presents significant in $1 \% ;{ }^{* *}$ Significant level presents significant in $5 \%$; ${ }^{*}$ Significant level presents significant in $10 \%$.

Table 3. Estimates of DID model (short-term).

\begin{tabular}{ccccc}
\hline Period & & \multicolumn{3}{c}{ Short-term-2007/1/1-2012/11/30 (announcement day: 2012/3/28) } \\
& & Experimental (TW)/comparison (HK) trading volume effect (Y) & p-value \\
\cline { 2 - 4 } & Coefficient & Standard error & t-statistic & 0.0000 \\
Intercept (C) & $9.953^{* * *}$ & 0.013528 & 735.8135 & 0.0000 \\
Time effect & $-0.236^{* * *}$ & 0.026389 & -8.951484 & 0.0000 \\
Economy effect & $1.508^{* * *}$ & 0.012589 & 119.8611 & 0.0017 \\
Cross effect & $-0.115^{* * *}$ & 0.036636 & -3.144748 & 0.7240 \\
Day return rate & 0.123 & 0.349840 & 0.353149 & 0.0000 \\
Amplitude rate & $9.505^{* * *}$ & 0.572518 & 16.60321 & 0.0000 \\
30-day return rate & $40.514^{* * *}$ & 2.079329 & 19.48444 & \\
R-squared & & 0.850049 & & \\
\hline
\end{tabular}

Notes: ${ }^{* * *}$ Significant level presents significant in $1 \% ;{ }^{* *}$ Significant level presents significant in 5\%; ${ }^{*}$ Significant level presents significant in $10 \%$. 
international factors such as the European debt crisis affected these two markets, exerting a significantly negative influence on trading volume in these two markets and reducing the trading volume by $23.6 \%$. We observed a significantly negative relationship at the $1 \%$ level in the cross-effect variable in the DID model during the short-term period in Taiwan. Applying the classical linear regression analysis to the short-term period revealed a $36.5 \%$ reduction in trading volume of Taiwan stock market. After the effects of international factors were controlled, the DID model was employed for the cross-effect analysis. Taiwan's stock trading volume continued to exhibit a decrease (11.5\%), indicating that the capital gains tax for securities had a negative short-term lock-in effect on Taiwan's stock trading volume.

\subsection{Long-Term Effects (Post Announcement)}

\section{1) Estimates of Classical Regression Model}

Table 4 shows that the trading volume of the Taiwan stock market declined by $28.1 \%$ in the long-term period. Although the trading volume remained negative in Hong Kong's stock market after extending the observation period and minimize the effects of international factors such as the European debt crisis, trading volume in the Hong Kong stock market declined by only 7\%. Thus, the effects of the European debt factor were weakened. Additionally, with the exception of the daily rate of return, the two other variables, daily amplitude rate and 30day rate of return, remained positively correlated at a $1 \%$ level of significance, indicating that the magnified stock market amplitude and long-term rates of return in the stock markets positively influenced the trading volume.

2) Estimates of Difference in Difference Model

As shown in Table 5, the time-effect variable indicates that in the long-term period, although the trading volume of the two stock markets remained negatively correlated with the common international factors, the extent of this influence decreased to only $9.8 \%$. A negative relationship at the $1 \%$ level of significance was observed when the DID model was employed to examine the cross-effect variable during this period in Taiwan. When applying the classical linear regression analysis on the long-term period revealed that the trading volume declined by $28.1 \%$. After the effects of international factors were controlled, the DID model was used for the cross-effect test. Trading volume in the Taiwan stock market still exhibited a $14.1 \%$ decrease, indicating that the capital gains tax for securities had a negative long-term lock-in effect on Taiwan’s stock trading volume.

\subsection{Causes and Tax Impact of the Lock-In Effect}

\section{1) Causes of Lock-In Effect}

From the aspect of elasticity demand for stock in Taiwan provides empirical evidence of the main causes of the lock-in effect in Taiwan's stock market. Regarding the investors' structure of the Taiwan stock market (approximately $32 \%$ - 42\% were professional corporate investors and approximately 58\% - 68\% were individual investors), individual investors account for the largest group of investors (Data sources: Taiwan Stock Exchange [17]). Because individual investors (who can be viewed as consumers of general financial services) usually do

Table 4. Estimates of classical regression model (long-term).

\begin{tabular}{|c|c|c|c|c|c|c|}
\hline \multirow[t]{4}{*}{ Period } & \multicolumn{6}{|c|}{ Long-term-2007/1/1-2014/9/29 (announcement day: 2012/3/28) } \\
\hline & \multicolumn{3}{|c|}{ Experimental group } & \multicolumn{3}{|c|}{ Comparison group } \\
\hline & \multicolumn{3}{|c|}{ Trading volume effect-TW (Y) } & \multicolumn{3}{|c|}{ Trading volume effect-HK (Y) } \\
\hline & Coefficient & Standard error & p-value & Coefficient & Standard error & p-value \\
\hline Constant & 11.532 & 0.013349 & 0.0000 & 9.890 & 9.890323 & 0.0000 \\
\hline Time effect & $-0.281^{* * *}$ & 0.013509 & 0.0000 & $-0.070^{* * *}$ & -0.070718 & 0.0000 \\
\hline Day return rate & 0.0592 & 0.451241 & 0.8955 & -0.085 & -0.085486 & 0.8425 \\
\hline Amplitude rate & $4.9093^{* * *}$ & 0.700061 & 0.0000 & $13.473^{* * *}$ & 13.47383 & 0.0000 \\
\hline 30-day return rate & $63.800^{* * *}$ & 2.453538 & 0.0000 & $21.327^{* * *}$ & 21.32731 & 0.0000 \\
\hline R-squared & & 0.414065 & & & 0.19218 & \\
\hline
\end{tabular}

Notes: ${ }^{* * *}$ Significant level presents significant in $1 \% ;{ }^{* *}$ Significant level presents significant in $5 \%$; ${ }^{*}$ Significant level presents significant in $10 \%$. 
Table 5. Estimates of DID model (long-term).

\begin{tabular}{|c|c|c|c|c|}
\hline \multirow[t]{3}{*}{ Period } & \multicolumn{4}{|c|}{ Long-term-2007/1/1-2014/9/29 (announcement day: 2012/3/28) } \\
\hline & \multicolumn{4}{|c|}{ Experimental (TW)/control (HK) trading volume effect } \\
\hline & Coefficient & Standard error & t-statistic & p-value \\
\hline Constant & 9.949 & 0.012671 & 785.1883 & 0.0000 \\
\hline Time effect & $-0.098^{* * *}$ & 0.015322 & -6.421686 & 0.0000 \\
\hline Economy effect & $1.509^{* * *}$ & 0.011930 & 126.5064 & 0.0000 \\
\hline Cross effect & $-0.141^{* * *}$ & 0.020909 & -6.780391 & 0.0000 \\
\hline Day return rate & 0.134 & 0.320719 & 0.419089 & 0.6752 \\
\hline Amplitude rate & $9.775^{* * * *}$ & 0.531551 & 18.39044 & 0.0000 \\
\hline 30-day return rate & $39.948^{* * * *}$ & 1.913139 & 20.88136 & 0.0000 \\
\hline R-squared & & 0.857528 & & \\
\hline
\end{tabular}

Notes: ${ }^{* * *}$ Significant level presents significant in $1 \% ;{ }^{* *}$ Significant level presents significant in 5\%; ${ }^{*}$ Significant level presents significant in $10 \%$.

not consider stock investments as necessity goods, their demand for stock is thus highly elastic. This differs from the European and United States stock market structures, which are dominated by corporate investors. Because capital gains tax for securities increases transaction costs for investors, thus, taxation is likely to generate a substitution effect to invest in low-tax and tax-free products for investors, which would cause a lock-in effect for securities market and substantial distortion in the allocation of resources. The tax levy on capital gains for securities in Taiwan in 2013 was imposed on both individual and legal entities investors. In the listed stock market, tax provisions were established for large individual investors with trading volume exceeding NT \$1 billion. Most investors (>60\%) in Taiwan's stock market are individual investors. Because stock investments are considered as nonessential goods and a diverse range of investment options are available in Taiwan, the demand elasticity of individual investors is relatively higher than professional corporate investors. Thus, the substitution effect resulting from the new capital gains tax for securities was particularly pronounced in Taiwan. On the other hand, the proportion of individual investors in Taiwan's stock market fell from $62.7 \%$ to $58.7 \%$ in the year following the announcement date, whereas the proportion of corporate investors increased from $37.3 \%$ to $41.3 \%$. These results further confirm the negative relationship between taxation and individual investor behavior. Introducing the capital gains tax for securities in 2013 caused reduction in investment willingness of stock market for individual investors. We hypothesized that the long-term lock-in effect influence on the stock market would continue unless the implicit trading concerns of the majority investors and rights protection measures were clarified.

2) Impact on Tax Revenue

The government of Taiwan imposed the capital gains tax for securities in 2013 intends to increase tax revenue and promote tax fairness and market efficiency. The empirical result reveals the policy induced a lock-in effect, leading to a $25 \%$ - 30\% reductions in trading volume in the Taiwan stock market. This tax policy led directly to a lock-in effect on stock market trading volume and caused a negative influence to another key source of tax revenue in Taiwan, reducing securities transactions tax revenue by NT $\$ 44.7$ billion within 2 years (compared with the period before the announcement date) (Data sources: Directorate General of Budget [22]). Prior to the announcement, the annual contribution of securities transactions tax revenue was at least NT \$100 billion (approximately $5 \%$ to $6 \%$ of all tax revenue) in Taiwan. Following the announcement, annual tax revenue was reduced by at least NT $\$ 22$ billion (approximately 20\%). The expected tax revenue of the Ministry of Finance [1] for the capital gains tax for securities was approximately NT $\$ 10$ billion from individual capital gains and approximately NT $\$ 4$ billion from corporate capital gains. Thus, the contribution of the capital gains tax for securities revenue to Taiwan's overall tax revenue structure was estimated to be only approximately $1 \%$. However, the levying of the tax on capital gains for securities reduced other tax revenues (such as securities transactions tax by at least $2 \%$ ). This loss appears to be greater than the gain. The lock-in effect on Taiwan's stock market trading volume has led to a depression in capital markets, increasing unemployment rates in securities market industry (Data sources: Taiwan Securities Association [23]). The overall social effects of the tax appear to have generated a loss greater than the gain. 


\section{Conclusions}

In this study, we used classical linear regression model and DID model while minimized the effects of international markets. The Taiwan stock market was the experimental group and the Hong Kong stock market, which was closely correlated with the Taiwan stock market, was the comparison group. We examined the short-term and long-term lock-in effects following the announcement of the capital gains tax for securities in 2013. The empirical results indicated that the changes in trading volume of the Taiwan stock market exhibited short-time and long-term lock-in effects caused by the capital gains tax for securities as compared with those in Hong Kong's stock market.

As for the short-term lock-in effect, the empirical results from regression method have found that the Taiwan stock market volume has decreased 36.5\% between the period from March, 282012 to November, 302012 which the contrast group of Hong Kong stock market has a reduction of $21.1 \%$. It demonstrates that such period has been influenced by international economic crisis such as European debt risks and other events. After applying the DID method to exclude international factors, the cross-effect examination result found that the Taiwan stock trading volume was still reduced by $11.5 \%$ indicating a short-term negative and significant lock-in effect. A further analysis of long-term lock-in effect during the period from March, 282012 to September, 292014 indicated that the stock trading volume of Taiwan has been still reduced by $28.1 \%$. That of the comparison group has only been reduced by $7 \%$ after the extension of observation period has diluted international influence factors such as European debt crisis. The DID model has shown that Taiwan's stock trading volume remains to be reduced by $14.1 \%$ after DID cross-effect examination which excludes international factors. The research results conclude that capital gains tax for securities has a long-term negative lock-in effect to Taiwan's stock trading volume.

The lock-in effect on Taiwan's stock trading volume caused a depression in Taiwan's stock market and reduced another key source of tax revenue for the government (the securities transaction tax). We offer the following suggestions for responding to this lock-in effect:

1) We suggest that the government should first understand the stock market structure and investor behavior before taxing on securities market investors. In accordance with the principle of tax neutrality, the demand elasticity of the subject of taxation (such as stock) should be analyzed and the taxation structure of the securities market as a whole should be systematically and comprehensively improved.

2) From the perspective of stock investors' demand elasticity, the subjects of the capital gains tax for securities, we suggest learning from Hong Kong capital gains tax system (Data sources: Inland Revenue Department [24]). Capital gains tax for securities shall levy priority on stock investment demand elasticity relatively smaller and professional individuals or business investors whom are more likely to earn profit from investing activity. To majority individual (whom has higher demand elasticity) levying tax might change their investing behavior and reduce investing willingness. Thus, the substitution effect and lock-in effect on stock trading volume caused by the capital gains tax for securities are significant.

\section{References}

[1] Ministry of Finance, Chinese Taipei. http://www.mof.gov.tw/

[2] Yin, Y.P. (2005) Theoretical Analysis on the Capital Market Tax System. Finance and Economics, 209, 68-72. (In Chinese)

[3] Feldstein, M. and Yitzhaki, S. (1978) The Effect of the Capital Gains Tax on the Selling and Switching of Common Stocks. Journal of Public Economics, 9, 17-36. http://dx.doi.org/10.1016/0047-2727(78)90024-5

[4] Jin, L. (2006) Capital Gain Tax Overhang and Price Pressure. Journal of Finance, 61, 1399-1430. http://dx.doi.org/10.1111/j.1540-6261.2006.00876.x

[5] Somers, M. (1948) An Economic Analysis of the Capital Gains Tax. National Tax Journal, 1, 226-232.

[6] Stiglitz, J.E. (1983) Some Aspects of the Taxation of Capital Gains. Journal of Public Economics, 21, 257-294. http://dx.doi.org/10.1016/0047-2727(83)90051-8

[7] Dai, Z., Maydew, E., Shackelford, D.A. and Zhang, H.H. (2008) Capital Gains Taxes and Asset Prices: Capitalization or Lock-In? Journal of Finance, 63, 709-742. http://dx.doi.org/10.1111/j.1540-6261.2008.01329.x

[8] Sahm, M. (2008) Methods of Capital Gains Taxation and the Impact on Asset Prices and Welfare. National Tax Journal, 61, 743-768. http://dx.doi.org/10.17310/ntj.2008.4.09 
[9] Poterba, J.M. (1987) Tax Evasion and Capital Gains Taxation. NBER Working Paper, No. W2119.

[10] Reese Jr., W.A. (1998) Capital Gains Taxation and Stock Market Activity: Evidence from IPOs. The Journal of Finance, 53, 1799-1819. http://dx.doi.org/10.1111/0022-1082.00073

[11] George, T.J. and Hwang, C.Y. (2007) Long-Term Return Reversals: Overreaction or Taxes? Journal of Finance, 62, 2865-2896. http://dx.doi.org/10.1111/j.1540-6261.2007.01295.x

[12] Falsetta, D., Rupert, T.J. and Wright, A.M. (2013) The Effect of the Timing and Direction of Capital Gain Tax Changes on Investment in Risky Assets. Accounting Review, 88, 499-520. http://dx.doi.org/10.2308/accr-50319

[13] Henderson, Y.K. (1990) Capital Gains Tax Rates and Stock Market Volume. National Tax Journal, 43, 411-425.

[14] Slemrod, J. (1982) Stock Transactions Volume and the 1978 Capital Gains Tax Reduction. Public Finance Quarterly, 10, 3-6. http://dx.doi.org/10.1177/109114218201000101

[15] Gemmill, R.F. (1956) The Effect of Capital Gains Tax on Asset Price. National Tax Journal, 9, 289-301.

[16] Bhootra, A. (2013) On the Role of Intangible Information and Capital Gains Taxes in Long-Term Return Reversals. Financial Management, 42, 537-573. http://dx.doi.org/10.1111/fima.12013

[17] Taiwan Stock Exchange. http://www.twse.com.tw/

[18] Hong Kong Stock Exchange. http://www.hkex.com.hk/

[19] Ashenfelter, O. and Card, D. (1985) Using the Longitudinal Structure of Earnings to Estimate the Effect of Training Programs. Review of Economics and Statistics, 67, 648-660. http://dx.doi.org/10.2307/1924810

[20] Lin, M.J. (2013) The Impact on Stock Turnover of Declaring Capital Gains Taxation in Taiwan Stock Market. Thesis, National Taiwan University, Taipei. (In Chinese)

[21] Lu, Y.J. (2002) The Interactive Relationship of Return and Volatility among Taiwan, Japan, U.S.A., Hong Kong and China Main Stock Markets. Thesis, National Taipei University, Taipei. (In Chinese)

[22] Directorate General of Budget, Accounting and Statistics, Executive Yuan. http://www.dgbas.gov.tw/

[23] Taiwan Securities Association (2014) Impact Assessment Report of Capital Gain Taxes. Taipei, October 2014. (In Chinese)

[24] Inland Revenue Department (IRD) http://www.ird.gov.hk/ 